Louisiana State University

LSU Digital Commons

$7-5-2004$

\title{
Elemental analysis of soft plaque and calcified plaque deposits from human coronary arteries and aorta
}

\author{
J. I. Murungi \\ Kenyatta University \\ S. Thiam \\ Louisiana State University \\ R. E. Tracy \\ Louisiana State University \\ J. W. Robinson \\ Louisiana State University \\ I. M. Warner \\ Louisiana State University
}

Follow this and additional works at: https://digitalcommons.Isu.edu/chemistry_pubs

\section{Recommended Citation}

Murungi, J., Thiam, S., Tracy, R., Robinson, J., \& Warner, I. (2004). Elemental analysis of soft plaque and calcified plaque deposits from human coronary arteries and aorta. Journal of Environmental Science and Health - Part A Toxic/Hazardous Substances and Environmental Engineering, 39 (6), 1487-1496.

https://doi.org/10.1081/ESE-120037848

This Article is brought to you for free and open access by the Department of Chemistry at LSU Digital Commons. It has been accepted for inclusion in Faculty Publications by an authorized administrator of LSU Digital Commons.

For more information, please contact ir@lsu.edu. 
Twenty-five samples of soft plaque and calcified plaque deposits from human hearts or aorta were analyzed using inductively coupled plasma-mass spectrometry (ICP-MS). The determined elements were $\mathrm{Ca}, \mathrm{P}, \mathrm{Na}, \mathrm{K}, \mathrm{Mg}, \mathrm{Zn}, \mathrm{Cu}, \mathrm{Ba}, \mathrm{Pb}, \mathrm{Fe}, \mathrm{Al}, \mathrm{Si}$, and $\mathrm{S}$. Results showed that the concentration of all elements in the soft plaque was at the micromolar level. In the calcified deposits, the concentrations of $\mathrm{Ca}$ and $\mathrm{P}$ were at least an order of magnitude higher than the soft plaque, but the other elements were at the same order of magnitude. In the calcified plaque the molar ratios of $\mathrm{Ca} / \mathrm{P}$ suggested that a significant portion existed as hydroxyapatite $\mathrm{Ca}_{10}\left(\mathrm{PO}_{4}\right)_{6}(\mathrm{OH})_{3}$. However, their absolute concentrations indicated that this compound was not a major component of the plaque although it may play a major role in determining the crystal structure of the deposit. In some samples the $\mathrm{Ca} / \mathrm{P}$ ratio was too high to conform to hydroxyapatite. In others it was too low. This indicated that both the calcium and phosphorus existed in other chemical forms which varied from sample to sample. In the soft tissue the P level was high indicating it existed primarily in chemical forms other than hydroxyapatite. The presence of homocysteine is often associated with heart disease. However, the low levels of sulfur indicate that although it may be present, it is not a major component of the plaque, but may nevertheless play an important role in its formation. 